\title{
Pengawasan Peraturan Daerah Pada Undang-Undang Nomor 23 Tahun 2014 tentang Pemerintahan Daerah
}

\author{
Fajri Nursyamsi*
}

\begin{abstract}
Abstrak
Perubahan Undang-Undang Nomor 32 Tahun 2004 menjadi Undang-Undang Nomor 23 Tahun 2014 tentang Pemerintahan Daerah semakin menegaskan hubungan yang sentralistik antara pemerintah pusat dan pemerintah daerah, yang selama pasca kemerdekaan mengalami dinamika yang tinggi, terutama dalam hal konsep dominasi kekuasaan antara keduanya. Salah satu dampak yang signifikan dari perubahan itu terletak pada kewenangan pengawasan pemerintah pusat terhadap peraturan daerah yang dibentuk oleh pemerintah daerah. Kondisi itu semakin memperkuat posisi pemerintah pusat terhadap pemerintah daerah. Di satu sisi, hal tersebut mempertegas konsep negara kesatuan, tetapi di sisi lain semakin membatasi kewenangan pemerintah daerah dalam melaksanakan otonomi daerah. Keduanya merupakan amanat dari Undang-Undang Dasar 1945. Kewenangan pengawasan juga berdampak kepada kewenangan pembatalan peraturan daerah oleh pemerintah pusat. Hal itu tidak bisa sekedar dilihat dari aspek hubungan antara pemerintah pusat dan daerah, tetapi juga berkaitan dengan perspektif perundang-undangan. Dengan adanya pembatalan, maka penting untuk melihat upaya hukum yang tersedia apabila ada yang tidak berkenan dengan pelaksanaan kewenangan pembatalan tersebut.
\end{abstract}

Kata Kunci: desentralisasi, kewenangan pengawasan, peraturan daerah, pemerintahan daerah, negara kesatuan.

\section{Supervision on Local Regulations in Law Number 23 of 2014 Concerning Regional Government}

\begin{abstract}
The amendment of Law Number 23 of 2004 with Law Number 23 of 2014 on Local Government has underlined the centralistic relationship between central and regional governments-both of which have undergone numerous changes throughout the postindependence period, specifically concerning authority domination. Among these changes is the central government's authority to supervise regional government in formulating local regulations; this reinforces the authority that the central government has over the regional governments. While this reaffirms the notion of unitary state, it also effectively limits the capacity of regional government in implementing regional autonomy, both of which are crucial to the 1945 Constitution. This supervisory authority consequently leads also to the central government's authority to cancel local regulations. By considering not only the
\end{abstract}

PADJADJARAN Jurnal IImu Hukum Volume 2 Nomor 3 Tahun 2015 [ISSN 2460-1543] [e-ISSN 2442-9325]

* Peneliti di Pusat Studi Hukum dan Kebijakan Indonesia (PSHK) dan Pengajar di Institute Jentera School of Law (IJSL), Puri Imperium Office Plaza UG 11-12, Jakarta, fajri.nursyamsi@pshk.or.id, S.H. (Universitas Indonesia). 
matter of authority but also legislation, it is clear that the imposition of such great limitation over the regional governments is an issue. Thus, it is important to identify any available legal attempts that can be used to counter the central government's nullification of local regulations.

Keywords: decentralization, supervisory authority, local regulation, local government, unitary state.

\section{A. Pendahuluan}

Kewenangan pembentukan peraturan daerah (perda) oleh pemerintah daerah merupakan ciri khas dari penerapan prinsip otonomi daerah berdasarkan asas desentralisasi. Di Indonesia, kewenangan pembentukan perda oleh pemerintah daerah merupakan kewenangan atribusi dari Pasal 18 ayat 6 Undang-Undang Dasar Negara Republik Indonesia 1945 amendemen (UUD 1945 amendemen). Kewenangan pembentukan peraturan daerah tetap harus sesuai dengan peran pemerintah daerah dalam konteks negara kesatuan, sehingga pelaksanaannya terbatas oleh kekuasaan dari pemerintah pusat. Hubungan antara pemerintah pusat dan pemerintah daerah inilah yang kerap menimbulkan permasalahan.

Dinamika hubungan antara pemerintahan di tingkat pusat dan daerah sangat bergantung kepada rezim politik yang sedang berkuasa saat itu. Di Indonesia, perubahan peta politik sangat terlihat setiap kali ada penggantian undang-undang yang mengatur perihal pemerintahan Indonesia di daerah. Pasca kemerdekaan, tercatat ada delapan undang-undang (UU) yang mengatur perihal pemerintahan Indonesia di daerah. Selama itu pula konsep hubungan antara pemerintahan pusat dan pemerintahan daerah terus berpindah, dari sentralisasi menjadi desentralisasi, dan begitu sebaliknya. Perubahan-perubahan itu sebenarnya lazim juga terjadi di berbagai negara, terutama di negara yang berbentuk kesatuan.

Bentuk dari keterikatan antara pemerintah pusat dan pemerintah daerah, terutama dalam menjalankan kewenangan pembentukan peraturan daerah, adalah adanya mekanisme pengawasan perda oleh pemerintah. Sebagai negara kesatuan, fungsi pengawasan di Indonesia sudah ada dari awal kemerdekaan, tetapi dalam konteks dan lingkup yang berbeda di antara ketentuan yang mengatur. Perbedaan itu juga terjadi pada perubahan UU tentang pemerintahan daerah yang terakhir. Perbedaan yang dapat dikatakan cukup mendasar, walaupun tetap berada pada lingkup otonomi daerah.

Kewenangan pengawasan pembentukan perda yang dimiliki oleh pemerintah dimungkinkan untuk berakhir kepada pembatalan atau revisi terhadap substansi perda bersangkutan. Pemerintah daerah memiliki hak untuk mengajukan keberatan, tetapi pengaturannya tetap memposisikan pemerintah pusat memiliki 
kewenangan yang lebih kuat. Dalam konteks ini, menarik untuk melihatnya dari perspektif otonomi daerah yang diberikan kewenangan untuk melaksanakan rumah tangganya sendiri. Selain itu, dalam perspektif teori perundang-undangan yang memiliki prinsip bahwa suatu peraturan perundang-undangan dapat dibatalkan oleh pejabat yang membentuk, atau oleh peraturan yang lebih tinggi.

\section{B. Konsep Pemerintahan Dalam Negara Kesatuan}

Sebelum masuk secara mendalam mengenai konsep pemerintahan, perlu terlebih dahulu dijabarkan mengenai dua bentuk negara yang umum dianut oleh berbagai negara di dunia saat ini, yaitu federal dan kesatuan. Setelah itu, pembahasan akan lebih fokus untuk melihat konsep pemerintahan yang ada di negara kesatuan. Analisis dilakukan dengan mendasarkan kepada teori pembagian kekuasaan, terutama pembagian kekuasaan secara vertikal, yaitu membagi pemerintahan dalam suatu negara menjadi pemerintahan di pusat dan daerah.

\section{Pembagian Negara Berdasarkan Kedaulatannya}

Menganalisis suatu negara dapat dilakukan dari berbagai sudut pandang dan pendekatan. Negara dapat dilihat dari aspek tujuannya, legitimasi kekuasaannya, dan asal mulanya. Pada kajian hukum tata negara, sudut pandang yang kerap digunakan dalam melihat negara adalah berdasarkan kepada struktur yang ada di dalamnya, terutama struktur kedaulatannya. Berdasarkan hal itu, I Dewa Gede Atmadja dalam bukunya, "Imu Negara", menyatakan bahwa negara terbagi atas tiga kelompok, yaitu negara kesatuan, negara federal/serikat, dan negara emperium. ${ }^{1}$ Bentuk negara yang dapat diperbandingkan pada dasarnya adalah negara kesatuan dan federal dengan melihat kepada pembagian kedaulatan pada internal negaranya. Sedangkan negara imperium lebih melihat kepada kondisi eksternal negaranya, karena secara internal negara imperium tetap berdaulat dan menganut bentuk negara federal atau kesatuan.

Seperti telah disebutkan sebelumnya bahwa perbedaan negara kesatuan dan federal terletak pada kedaulatannya, yakni apakah terbagi di pusat dan daerah (negara federal) atau terpusat di pemerintah pusat (negara kesatuan)? Keduanya memiliki konsekuensi yang berbeda, baik terhadap struktur ketatanegaraannya atau juga dalam konteks administrasi negara. Pada bentuk negara federal, setiap negara bagian memiliki kewenangan sekaligus kedaulatan untuk membentuk peraturan yang mengikat secara umum masyarakat di wilayahnya tanpa terikat dengan peraturan yang dibentuk oleh negara federal. Bahkan, negara bagian dapat membentuk konstitusinya sendiri, berbeda dengan konstitusi di negara federal. Pada negara kesatuan, pemerintah daerah memiliki kewenangan dalam membentuk peraturan, sebagai bentuk dari pelaksanaan asas desentralisasi, tetapi

1 I Dewa Gede Atmadja, Ilmu Negara, Malang: Setara Press, 2011, hlm. 139. 
ketetuannya terikat dengan peraturan atau hukum yang dibentuk oleh pemerintah. Kebanyakan negara kontemporer berbentuk negara kesatuan. ${ }^{2}$ C.F. Strong menyatakan bahwa esensi dari suatu negara kesatuan adalah kedaulatannya yang tidak terpisah, atau dengan kata lain kekuasaan pemerintah pusat yang tidak terbagi. ${ }^{3}$ Konstitusi pada negara kesatuan tidak membagi kewenangan pembentukan undang-undang pada lembaga legislatif yang berada di pemerintah pusat. Namun begitu, secara kelembagaan bukan berarti pemerintahan daerah tidak memiliki kewenangan sama sekali untuk membentuk peraturan, tetapi pemerintah pusat memiliki kewenangan untuk membatalkan apabila tidak sesuai dengan kebijakannya. ${ }^{4}$ Pemerintahan daerah dapat memiliki kebijakan untuk dilaksanakan, tetapi tetap dengan izin dari pemerintahan pusat. ${ }^{5}$

\section{Pembagian Kekuasaan dalam Negara Kesatuan}

Dalam analisis pemerintahan suatu negara kesatuan harus terlebih dahulu dilihat akar teorinya, yaitu tentang pembagian kekuasaan. Teori pembagian kekuasaan yang dikenal sekarang merupakan pengembangan dari teori pemisahan kekuasaan, yang pada awalnya berkembang sebagai bentuk demokratisasi dan pembatasan kekuasaan. ${ }^{6}$ Teori klasik mengenai pemisahan kekuasaan yang dikemukakan oleh Montesquieu mencakup tiga kekuasaan, yaitu kekuasaan eksekutif, legislatif, dan yudisial. ${ }^{7}$ Pembagian cabang kekuasaan itu diperlukan untuk menghindari adanya kesewenang-wenangan, ${ }^{8}$ yang pada saat itu marak terjadi di negeri Perancis. ${ }^{9}$

2 Rod Hague dan Martin Harrop, Comparative Government and Politics, Fourth Edition, New York: Palgrave, 2001, hlm. 208. Lihat juga, Bhenyamin Hoessein, Perubahan Model, Pola, dan Bentuk Pemerintahan Daerah, Jakarta: Departemen Ilmu Administrasi FISIP UI, 2011, hlm. 105.

3 C.F. Strong, Modern Political Constitutions, London: Sidgwick \& Jackson Limited, 1958, hlm. 80.

4 lbid.

5 Rod Hague dan Martin Harrop, Loc.cit.

6 Fitriani Ahlan Sjarif, "Pengawasan Peraturan Daerah dalam Kerangka Negara Kesatuan (Tinjauan Historis dan Perbandingan Menurut UU Nomor 5 Tahun 1974, UU Nomor 22 Tahun 1999 dan UU Nomor 32 tahun 2004)", Tesis Pascasarjana FHUI, Jakarta, 2005, hlm. 18.

7 Fungsi kekuasaan legislatif adalah untuk membuat aturan, kekuasaan eksekutif menjalankan aturan tersebut, sedangkan kekuasaan yudisial menilai konflik atau perselisihan yang terjadi dalam pelaksanaan aturan itu dan menerapkan norma aturan itu untuk menyelesaikan konflik atau perselisihan; dalam Charles Louis Montesquieu, Complete Works Vol 1 The Spirits of Law, Indiana: Liberty Fund Inc., 2009, hlm. 213. Lihat juga, Jimly Asshiddiqie, Pengantar IImu Hukum Tata Negara Jilid II, Jakarta: Sekretariat Jenderal MK RI, 2006, hlm. 21.

8 Ada pendapat terkenal terkait dengan kekuasaan yang sewenang-wenang yang dikemukakan oleh Lord Acton bahwa, "Power tends to corrupt, and absolute power corrupts absolutely."

9 Pandangan tersebut merupakan kritik terhadap pendapat tentang konsep kedaulatan yang berkembang pada abad ke-11 dan awal abad ke-12 yang dikemukakan oleh John Austin dan J.J Rousseau. Pada pandangan tersebut disebutkan bahwa kedaulatan bersifat bulat atau suatu kesatuan, dalam pengertian bahwa kemauan umum rakyat adalah suatu kesatuan yang berhak memerintah dan berhak menolak untuk diperintah. Dalam konteks rakyat adalah satu, maka negara juga adalah satu, sehingga konsep kedaulatan pun bersifat bulat dan tak dapat dipecah-pecah (indivisible). Apabila yang berdaulat adalah raja, maka rajalah yang merupakan satu-satunya pemegang kekuasaan tertinggi dalam negara. Sebaliknya, apabila rakyat berdaulat, maka rakyat pulalah satusatunya pemegang kekuasaan tertinggi, bukan yang lain. Lihat, Jimly Asshiddiqie, "Konstitusi dan Konstitualisme", http://jimly.com/pemikiran, diakses 20 Februari 2013, hlm. 102. 
Dalam penerapannya, pemisahan kekuasaan tidak dilakukan secara mutlak antara ketiga kekuasaan tersebut. Pada konteks ini mulai dikenal adanya teori checks and balances yang lahir dari kritik terhadap teori pemisahan kekuasaan murni dan berpandangan bahwa pada dasarnya cabang kekuasaan yang ada berkaitan satu sama lain, sehingga pelaksanaan fungsinya tidak bisa dipisahkan secara ketat. Tokoh yang terkemuka dalam teori pemisahan kekuasaan adalah John Locke dan Montesquieu. Setelah itu muncul tokoh lain yang mengembangkannya, yaitu seperti Arthur Mass dan G.Marshall. Nama terakhir itu sudah mulai memasukkan checks and balances sebagai salah satu dari lima aspek dalam pemisahan kekuasaan, yang terdiri dari differentiation legal incompatibility of office holding; isolation, immunity, and independence; checks and balances; dan coordinate status and lack of accountability. ${ }^{10}$

Salah satu bentuk nyata dari berkembangnya teori check and balances dalam suatu negara modern adalah hadirnya mahkamah konstitusi dalam sistem ketatanegaraannya. Prinsip checks and balances pada suatu negara akan bertambah kuat karena mahkamah konstitusi (constitutional courts) ini hadir di antara cabang kekuasaan yang sengaja dipisah-pisahkan. Salah satu buktinya tercermin dari kewenangannya, yaitu melakukan judicial review. ${ }^{11}$ Sesuai dengan kewenangan itu, mahkamah konstitusi yang merupakan bagian dari kekuasaan yudisial menguji konstitusionalitas undang-undang yang merupakan produk lembaga legislatif, dan memutus berkenaan dengan berbagai bentuk sengketa antar lembaga negara yang berada dalam berbagai cabang kekuasaan pada suatu negara.

Perkembangan lain dari teori pemisahan kekuasaan adalah lahirnya teori pembagian kekuasaan. Miriam Budiarjo menyatakan bahwa pembagian kekuasaan dapat dilakukan secara vertikal dan horizontal. Pembagian kekuasaan secara vertikal dilakukan berdasarkan tingkatannya, yaitu pembagian terhadap kekuasaan dalam pemerintahan. ${ }^{12}$ Carl J. Friedrich mengungkapkan hal yang sama dengan istilah pembagian kekuasaan secara teritorial. Secara lebih tegas, pembagian kekuasaan vertikal itu adalah pembagian kekuasaan antara pemerintah daerah dan pemerintah pusat dalam suatu negara kesatuan, negara federal, atau negara konfederasi. Pada negara kesatuan, menurut C.F. Strong yang juga dikutip oleh Bhenyamin Hoessein dalam bukunya, disebutkan bahwa hubungan antara pemerintah pusat dan pemerintah daerahnya adalah dependent dan subordinate. ${ }^{13}$

\footnotetext{
10 Jimly Asshiddiqie, Pengantar..., Loc.cit.

11 Pada umumnya, judicial review merupakan kewenangan dari kekuasaan yudisial. Hal itu ditegaskan oleh Khaterine Lindsay dalam bukunya yang berjudul Federal Constitutional Law, sebagaimana dikutip oleh Laica Marzuki dalam buku "Berjalan-jalan di Ranah Hukum" bahwa, "in which a superior court had power to determine question of constitutional validity of enactment of the legislature". Lihat Eric Barendt, An Introduction to Costitutional Law, Oxford: Oxford University Press, 1998, hlm.

12 Miriam Budiarjo, Dasar-dasar Ilmu Politik, Jakarta: Gramedia Pustaka Utama, 1998, hlm. 138.

13 Bhenyamin Hoessein, Op.cit., hlm. 217.
} 
Seperti halnya pemisahan kekuasaan, pembagian kekuasaan secara vertikal pun pada akhirnya tidak bisa dilakukan secara mutlak, termasuk dalam negara kesatuan. Menurut Goodnow, pengatur hubungan antara pusat dan daerah merupakan hal yang tidak logis, karena pada satu sisi pemerintahan lokal perlu diberikan hak untuk menentukan keinginannya sendiri tanpa mengurangi kedaulatan suatu negara. Namun, di sisi lain menjadi suatu kemustahilan untuk melaksanakan kebijakan dari pemerintah pusat apabila bertentangan dengan keinginan pemerintah daerah. Oleh karena itu, dalam suatu negara kesatuan diperlukan tujuan dan pelaksanaan yang harmonis dalam keseluruhan negara. ${ }^{14}$

Pemikiran tersebut menjadi dasar munculnya konsep pemerintahan yang menganut sistem sentralisasi dan desentralisasi dalam negara kesatuan. Pemikiran mengenai sentralisasi dan desentralisasi pada pelaksanaan pemerintahan di daerah bersumber pada anggapan bahwa salah satu dari pemerintah pusat atau pemerintah daerah harus ada yang lebih berkuasa. ${ }^{15}$ Apabila tidak, akan berpotensi menimbulkan konflik antara keduanya. Konflik yang muncul disebabkan karena cakupan kerja dari masing-masing pemerintahan yang beririsan. ${ }^{16}$ Berdasarkan pandangan filosofis dan politik, pada suatu negara hukum yang pengaturan tertingginya adalah konstitusi, maka lembaga yang berwenang untuk menginterpretasikan suatu peraturan perundang-undangan (termasuk pembatalan) haruslah tegas berada di pemeritahan pusat atau daerah, karena interpretasi yang diberikan akan sangat dipengaruhi oleh pandangan politik dari tempatnya berasal. ${ }^{17}$

Pemahaman mengenai sentralisasi dan desentralisasi pada dasarnya tidak dapat dipisahkan. Bukan berarti desentralisasi merupakan kebalikan dari sentralisasi, karena pada dasarnya suatu negara sebagai organisasi secara natural akan menganut asas sentralisasi sejak awal pembentukannya sampai akhir hayatnya. ${ }^{18} \mathrm{Hal}$ tersebut terjadi karena dalam pelaksanaannya tidak mungkin berjalan secara efektif, terlebih peran negara sudah semakin kompleks dalam tataran negara modern, maka dianutlah asas desentralisasi. Penyelenggaraan desentralisasi selalu dilakukan dalam lingkup unsur sentralisasi. Dalam konteks negara kesatuan, desentralisasi diselenggarakan oleh pemerintah pusat, sedangkan dalam negara federal asas desentralisasi dijalankan oleh pemerintah negara bagian.

\section{Pengawasan Pemerintah Pusat terhadap Peraturan Daerah}

Pada hubungan antara pemerintah pusat dan daerah, makna pengawasan memiliki

\footnotetext{
14 Frank J. Goodnow, Politics and Administration, America: Transaction Publisher, 2003, hlm. 51.

15 Ibid., hlm. 48.

16 Ibid.

17 Ibid.

${ }^{18}$ Bhenyamin Hoessein, Op.cit., hlm. 150.
} 
peran yang penting dan strategis dalam menjaga tata pemerintahan dalam suatu negara kesatuan. Pengawasan dalam konteks tersebut bermakna sebagai pengikat antara pemerintah pusat dan daerah. Pengawasan menjadi penting untuk menjaga kebebasan yang dimiliki oleh pemerintah daerah agar bandul otonomi tidak bergerak jauh melebihi garis edar sehingga dapat mengancam tatanan kesatuan (unitary) dalam pengelolaan negara.

Sejalan konteks tersebut, O. Hart sebagaimana dikutip oleh Ni'matul Huda dalam bukunya yang berjudul "Problematika Pembatalan Perda", berpendapat bahwa, "....if local autonomy is not to produce a state affairs bordering on anarchy, it must subordinated to national interest by means devised to keep its action within bounds". ${ }^{19}$ Tema mengenai pengawasan atau review perda semakin relevan di antara isu desentralisasi dan penguatan kewenangan legislasi daerah. Perda menjadi salah satu instrumen yang strategis untuk mewujudkan tujuan desentralisasi. Di sisi lain, keberadaan perda juga merupakan implementasi sistem representasi dalam perumusan kebijakan di tingkat pemerintahan daerah.

Pada konteks hubungan pemerintahan pusat dan daerah di negara kesatuan, peran lembaga legislatif tidak begitu penting, yang lebih penting adalah otoritas administrasi. Lembaga legislatif hanya membentuk peraturan dalam prinsip umum, sedangkan dalam membentuk peraturan yang lebih detail dilakukan oleh lembaga eksekutif yang juga memegang otoritas administrasi untuk kemudian dilaksanakan oleh masyarakat di tingkat daerah. ${ }^{20}$ Oleh karena itu, fungsi pengawasan oleh pemerintah pusat hadir agar tidak terjadi konflik antar kewenangan.

Pengawasan dari pemerintah pusat kepada pemerintah daerah yang umum dilakukan adalah dalam bentuk pengawasan preventif dan pengawasan represif. I Gde Pantja Astawa menyatakan bahwa secara garis besar perbedaan antara keduanya adalah pengawasan preventif yang dilakukan sebelum perda disahkan, sedangkan pengawasan represif dilakukan setelah perda disahkan. Berdasarkan akibat hukumnya, pengawasan preventif belum menyentuh akibat hukum yang timbul karena status perda belum disahkan, sedangkan dalam pengawasan represif sudah memperhitungkan akibat hukum yang timbul pada saat keberlakuannya. ${ }^{21}$ Bagir Manan menyatakan bahwa pengawasan preventif memiliki aspek positif, yaitu dapat mengendalikan inisiatif yang dilakukan oleh daerah, sehingga daerah dipaksa untuk mengikuti kebijakan dari pemerintah pusat. ${ }^{22}$

\footnotetext{
19 Lihat Ni'matul Huda, Problematika Pembatalan Perda, Yogyakarta: FH UII Press, 2010.

${ }^{20}$ Frank J. Goodnow, Op.cit., hlm. 66.

21 I Gde Pantja Astawa, Problematika Hukum Otonomi Daerah di Indonesia, Bandung: Alumni, 2009, hlm. 322-323.

22 Bagir Manan, Menyongsong Fajar Otonomi Daerah, Yogyakarta: Pusat Studi Hukum Fakultas Hukum UII, 2001, hlm. 154.
} 


\section{Perkembangan Pengawasan Pemerintah Pusat Terhadap Peraturan Daerah Dalam Tinjauan Normatif}

Indonesia merupakan negara kesatuan yang menerapkan prinsip otonomi dan asas desentralisasi dalam pelaksanaan pemerintahan daerah. Pada praktiknya, konsep hubungan pemerintah pusat dan daerah berjalan di bawah komando politik hukum rezim yang berkuasa. Kondisi itu membuat pelaksanaan otonomi daerah dan asas desentralisasi tidak sama dari waktu ke waktu. Perubahan yang terjadi termasuk ketika Indonesia menjalankan bentuk negara federal, walaupun hanya dalam jangka waktu yang singkat.

Pasca kemerdekaan pada 1945, Indonesia sudah memberlakukan empat konstitusi, yaitu Undang-Undang Dasar 1945 pra amendemen (UUD 1945) UndangUndang Dasar Republik Indonesia Serikat 1949 (UUD RIS 1949) Undang-Undang Dasar Sementara 1950 (UUDS 1950) dan UUD 1945 amandemen. Masing-masing konstitusi, walaupun dalam bentuk negara yang berbeda, mengatur hubungan pemerintah pusat dan pemerintah daerah. Selain itu, masing-masing konstitusi memiliki UU organik tersendiri yang mengatur sistem pemerintah Indonesia di daerah. Keseluruhan ketentuan mengakui bahwa ada hubungan hierarki antara pemerintah pusat dan pemerintah daerah, seperti apa yang dikemukakan oleh Jimly Asshiddiqie bahwa makna dari frasa "dibagi atas" dalam ketentuan Pasal 18 ayat (1) UUD RI 1945 merujuk kepada hubungan pemerintah pusat dan daerah yang bersifat hierarkis dan vertikal. ${ }^{23}$ Pada penjelasan berikutnya akan dianalisis mengenai dinamika hubungan pemerintahan pusat dan daerah pada masingmasing UU organik yang dimaksud. Pembahasan tersebut akan difokuskan kepada hubungan pengawasan yang dilakukan oleh pemerintah pusat terhadap perda yang dibentuk oleh pemerintah daerah.

\section{Pengawasan Pada Awal Masa Kemerdekaan Berdasarkan UU Nomor 1 Tahun 1945}

Praktik pembagian kekuasaan secara vertikal di Indonesia sudah dilakukan sejak sebelum masa kemerdekaan. Pada awalnya pembagian ini bersifat sentralistis, ${ }^{24}$ selayaknya pemerintahan di negara-negara otoritarian pada umumnya. ${ }^{25}$ Sistem pemerintahan jajahan di Indonesia kemudian beralih menjadi sistem desentralisasi pada Tahun 1893. Pada tahun 1903, untuk pertama kalinya dibentuk UndangUndang Desentralisasi $1903 .^{26}$

\footnotetext{
23 Jimly Asshiddiqie, Konsolidasi Naskah UUD 1945 Setelah Perubahan Keempat, Jakarta: Pusat Studi Hukum Tata Negara FHUI, 2002, hlm. 21.

${ }^{24}$ Sistem sentralistis dilakukan berdasarkan kepada Regerings Reglement yang dibentuk oleh Staten General (Parlemen Kerajaan Belanda). Lihat Fitriani Ahlan Sjarif, Op.cit., hlm. 93.

25 Seperti halnya dilakukan oleh pemerintahan di negara-negara otoritarian. Lihat Satya Arinanto, Hak Asasi Manusia dan Transisi Politik di Indonesia, Jakarta: Pusat Studi Hukum Tata Negara FH UI, 2008, hlm. 98.

${ }^{26}$ Fitriani Ahlan Sjarif, Op.cit., hlm. 94.
} 
Pasca disahkannya UUD 1945, UU pertama yang dibentuk terkait dengan pemerintahan Indonesia di daerah adalah Undang-Undang Nomor 1 Tahun 1945 tentang Peraturan Mengenai Kedudukan Komite Nasional Daerah (Undang-Undang ini sering juga disebut sebagai Undang-Undang Desenteralisasi karena UU ini merupakan UU pertama yang mengatur tentang desentralisasi, selanjutnya disebut UU No. 1 Tahun 1945). UU itu hanya mengatur enam pasal, dan substansinya pun tidak terlalu detail dibandingkan dengan UU yang dibentuk dengan tema yang sama setelahnya. Pada pasal 2 UU ini diatur mengenai pelaksanaan otonomi daerah yang merupakan amanat dari Pasal 18 dan 20 UUD 1945. Dalam menjalankannya, dibentuklah Komite Nasional Daerah yang bertindak sebagai Badan Perwakilan yang dipimpin oleh kepala daerah. Pada Pasal 3 dan 4 diatur mengenai anggota Komite Nasional Daerah.

Secara umum, pada UU Nomor 1 Tahun 1945 tidak diatur secara eksplisit mengenai pengawasan pemerintahan pusat terhadap pemerintah daerah. Namun begitu, dalam Pasal 2 diatur bahwa, “... asal tidak bertentangan dengan Peraturan Pemerintah Pusat dan Pemerintah Daerah jang lebih luas dari padanja". Kalimat itu dengan tegas menyatakan bahwa prinsip otonomi daerah dilaksanakan secara terbatas. Pada pelaksanaannya pun fungsi pengawasan tetap dijalankan demi mendapatkan keharmonisan kebijakan secara nasional.

\section{Pengawasan Pemerintah Pusat Selama Masa Orde Lama}

UU Nomor 1 Tahun 1945 kemudian diubah menjadi Undang-Undang Nomor 22 Tahun 1948 tentang Penetapan Aturan-Aturan Pokok Mengenai Pemerintahan Sendiri di Daerah-Daerah yang Berhak Mengatur dan Mengurus Rumah Tangganya Sendiri (selanjutnya disebut UU Pemda 1948). UU yang baru tersebut sudah mulai mengatur perihal pemerintahan di daerah secara detail, sehingga tidak hanya mengatur mengenai prinsip-prinsip umum yang sebenarnya sudah digariskan dalam UUD 1945. Di dalam UU yang disahkan di Yogyakarta pada 10 Juli 1948 tersebut, diatur bahwa setiap daerah memiliki kekuasaan untuk mengatur dan mengurus rumah tangganya sendiri, serta melaksanakan medebewind atau hak untuk menjalankan peraturan dari pemerintah pusat atau daerah tingkat atasannya berdasarkan perintah daerah atasan tersebut. ${ }^{27}$ Kekuasaan pemerintahan dibuat berjenjang dengan mengatur bahwa daerah berada di bawah instansi atasannya, yaitu provinsi dibawah presiden, sedangkan provinsi sendiri mengawasi

27 Dalam Penjelasan Undang-Undang Nomor 22 Tahun 1948 tentang Penetapan Aturan-Aturan Pokok mengenai Pemerintahan Sendiri di Daerah-Daerah yang Berhak Mengatur dan Mengurus Rumah Tangganya Sendiri pada halaman 12 disebutkan bahwa mekanisme penyerahan kekuasaan dibagi menjadi dua, yaitu: penyerahan penuh, artinya baik tentang asasnya (prinsip-prinsipnya) maupun tentang caranya menjalankan kewajibannya (pekerjaan), diserahkan seluruhnya kepada daerah (hak otonomi); dan penyerahan tidak penuh, artinya penyerahan hanya mengenai caranya menjalankan saja, sedangkan prinsip-prinsipnya (asas-asasnya) ditetapkan oleh Pemerintah Pusat sendiri (hak medebewind). 
kabupaten/kota, begitupun kabupaten/kota besar mengawasai desa/kota kecil dibawahnya. UU Pemda 1948 tidak sempat berlaku lama, karena status Negara Indonesia sudah berubah menjadi federal berdasarkan Konferensi Meja Bundar pada 27 Desember $1949 .{ }^{28}$

UU Pemda 1948 terus berlaku sampai digantikan oleh Undang-Undang Nomor 1 Tahun 1957 tentang Pokok-Pokok Pemerintahan (UU Pokok-Pokok Pemerintahan 1957). UU tersebut dibentuk dengan mendasarkan kepada UUDS $1950 .{ }^{29}$ Politik hukum dalam membentuk UU Pokok-Pokok Pemerintahan 1957 berbeda dengan UU Nomor 22 Tahun 1948. Perubahan yang paling mendasar dalam konteks hubungan pemerintah pusat dan pemerintah daerah adalah adanya upaya untuk meminimalkan penggunaan asas sentralisasi dengan menyebutkan bahwa kepala daerah bukan alat pemerintah pusat, sehingga tidak bergantung kepada pemerintah pusat.

Keberlakuan dari UU Pokok-Pokok Pemerintahan 1957 tidak berlaku sepenuhnya karena dua tahun setelah pengesahannya Presiden Soekarno mengeluarkan Dekrit 5 Juli 1959 yang mengembalikan keberlakuan UUD 1945. Dalam nuansa Dekrit 5 Juli 1959, pemerintah mengeluarkan Penetapan Presiden (Penpres) Nomor 6 Tahun 1959 dan selanjutnya dibentuk pula Penpres Nomor 5 Tahun 1960. Kedua penpres itu secara tegas mengembalikan pengelolaan pemerintahan di daerah dari desentralisasi berdasarkan UU Pokok-Pokok Pemerintahan 1957, kembali menjadi sentralisasi.

Pasca Presiden Soekarno mengeluarkan dua penpres tersebut untuk mengembalikan pengelolaan pemerintahan menjadi sentralisasi, pada tahun 1965 dibentuklah UU Nomor 18 Tahun 1965 tentang Pokok-Pokok Pemerintahan (UU Pokok-Pokok Pemerintahan 1965). Selain menegaskan penggunaan asas sentralisasi, pembentukan UU Pokok-Pokok Pemerintahan 1965 juga dianggap mengakhiri kesimpangsiuran peraturan perihal pemerintahan di daerah, yang saat itu dianggap mengalami kelemahan demokrasi liberal. ${ }^{30}$ Pengesahan UU tersebut juga mengakhiri berlakunya peraturan lainnya, yaitu UU Nomor Pokok-Pokok Pemerintahan 1957, Penpres Nomor 6 Tahun 1959, Penpres Nomor 2 Tahun 1960,

\footnotetext{
28 Pada masa Undang-Undang Dasar Republik Indonesia Serikat 1949 (UUD RIS 1949), UU Nomor 22 Tahun 1948 tidak dicabut, tetapi justru dilengkapi dengan Undang-Undang Negara Indonesia Timur Nomor 44 tahun 1950 (UU NIT Nomor 44 Tahun 1950), yang dibentuk sebagai akibat dari bentuk negara federal yang dianut Indonesia dalam UUD RIS 1949. Seakan mengalami nasib yang sama dengan UU Nomor 22 Tahun 1948, UU NIT Nomor 44 Tahun 1950 juga tidak berlaku lama, karena NIT kemudian dibubarkan untuk bersatu kembali pada negara kesatuan dan diberlakukannya Undang-Undang Dasar Sementara 1950 (UUDS 1950).

29 Pengaturan mengenai pemerintahan di daerah pada UUDS 1950 diatur pada Bab IV. Pada Pasal 131 ayat 2 UUDS 1950 dinyatakan bahwa daerah-daerah diberikan otonomi seluas-luasnya untuk mengurus rumah tangganya sendiri.

30 Pembentukan UU Pemda 1965 merupakan pelaksanaan dari Ketetapan Majelis Permusyawaratan Rakyat Sementara (Tap MPRS) No.II/MPRS/1960 mengamanatkan adanya undang-undang tentang pemerintahan daerah yang stabil dan berkewibawaan mencerminkan kehendak rakyat, revolusioner dan gotong royong, serta terjaminnya keutuhan NKRI.
} 
dan Penpres Nomor 5 Tahun 1960.

Pengawasan yang dilakukan oleh pemerintah pusat terhadap perda yang dibentuk oleh pemerintah daerah adalah dengan pengawasan preventif dan represif, sedangkan pengawasan umum dilakukan terhadap pelaksanaan kewenangan pemerintahan daerah lain. Pengawasan preventif berarti bahwa suatu perda mengenai pokok-pokok tertentu tidak berlaku sebelum disahkan oleh pemerintah pusat, dalam hal ini Menteri Dalam Negeri. Pengawasan represif dilakukan dalam bentuk menangguhkan atau membatalkan suatu perda yang bertentangan dengan kepentingan umum atau dengan peraturan perundangan yang lebih tinggi. ${ }^{31}$

\section{Pengawasan Peraturan Daerah Pada Masa Orde Baru}

Memasuki rezim Orde Baru, pengaturan mengenai pemerintahan di daerah mengalami perubahan kembali, yaitu menjadi Undang-Undang Nomor 5 Tahun 1974 tentang Pokok-Pokok Pemerintahan Daerah (UU Nomor 5 UU Pokok-Pokok Pemda 1974). Walaupun berubah, tetapi asas sentralisasi masih kental diberlakukan, tetapi dalam UU ini kekuasaan dari pemerintahan daerah diperkecil. ${ }^{32}$ Dalam penelitian yang dilakukan oleh Mahfud MD disebutkan bahwa periode waktu 1969-1998 menunjukkan konfigurasi politik yang otoriter, yang dicirikan dengan pola hubungan pemerintah pusat dan pemerintah daerah yang sentralistik dan mengedepankan asas dekonsentrasi. ${ }^{33}$

Sama halnya dengan UU Pokok-Pokok Pemerintahan 1965, pengawasan yang dilakukan terhadap perda pada UU Pokok-Pokok Pemda 1974 juga melingkupi pengawasan preventif dan represif. Pengawasan preventif diatur dalam Pasal 68 dan 69, sedangkan pengawasan represif diatur dalam Pasal 70. Konsep pengawasan pada kedua ketentuan tersebut tidak berbeda jauh, hanya ada penjelasan yang lebih komprehensif terhadap ketentuan dalam UU Pokok-Pokok Pemda 1974.

\section{Pengawasan Peraturan Daerah Pada Masa Reformasi}

Pasca tahun 1999, ketika rezim sudah masuk dalam masa reformasi, dibentuk UU baru menggantikan UU Pokok-Pokok Pemda 1974, yaitu Undang-Undang Nomor 22 Tahun 1999 tentang Pemerintah Daerah (UU Pemda 1999). Dorongan untuk memberikan kebebasan yang luas kepada daerah sangat terlihat dalam substansi UU ini. Desakan itu muncul berdasarkan pengalaman buruk yang terjadi selama dikuasai oleh rezim otoriter sehingga seolah-olah pada awal Orde Reformasi pemerintah daerah mendapatkan kekuasaan berlebih, bahkan cenderung menggerogoti kekuasaan yang sesungguhnya dimiliki oleh pemerintah pusat. Pendulum berpindah kearah desentralisasi yang kental dengan aroma kebebasan daerah dalam menentukan nasibnya, bahkan dengan kondisi bertentangan dengan

\footnotetext{
31 Penjelasan Umum UU Pemda 1985.

32 Fitriani, Op.cit., hlm. 107.

${ }^{33}$ Mahfud M. D., Pergulatan Politik dan Hukum di Indonesia, Jakarta: Gama Medika, 1999, hlm. 197.
} 
pemerintah pusat sekalipun. Dalam periode ini, desentralisasi lebih terasa sebagai suatu kebebasan tanpa batas bagi daerah. ${ }^{34}$

Seolah ingin memperbaiki apa yang diatur dalam UU Pemda 1999, selanjutnya dibentuk Undang-Undang Nomor 32 Tahun 2004 tentang Pemerintahan Daerah (UU Pemda 2004) yang kembali menggerakan pendulum ke arah sentralisasi. Namun begitu, UU ini tidak melakukannya secara penuh karena masih kuatnya pengaruh euforia demokrasi pasca reformasi dan lepasnya rezim kekuasaan Orde Baru yang otoritarian. Hal itulah yang menjadikan pengaturan mengenai konsep sentralisasi dalam UU Pemda 2004 tidak mencolok. ${ }^{35}$

Pada UU Pemda 1999, pengawasan terhadap perda hanya dilakukan dengan cara represif, atau dengan tidak mengenal pengawasan preventif. Hal itu selaras dengan semangat mengurangi kekuasaan dari pemerintah pusat, tetapi juga tidak menghilangkan esensi dari konsep negara kesatuan. Hasilnya, sejak UU Pemda 1999 disahkan jumlah perda yang diterbitkan melonjak tajam. Sampai pertengahan 2002, jumlah perda yang dihasilkan 368 kabupaten/kota di Indonesia telah mencapai sekitar 6.000 perda. Sejumlah 645 perda diantaranya dibatalkan oleh pemerintah dalam kurun waktu 3 tahun, yaitu tahun 1999 hingga 2002. Hal tersebut menjadi salah satu evaluasi dalam mengubah mekanisme pengawasan UU Pemda 1999. Pada UU penggantinya, yaitu UU Pemda 2004, pengawasan preventif kembali diatur khusus untuk beberapa jenis perda saja, yaitu pajak daerah, retribusi daerah, Anggaran dan Pendapatan Belanja Daerah (APBD), dan Rencana Umum Tata Ruang (RUTR). Sedangkan, pengawasan represif dilakukan terhadap seluruh perda yang dibentuk oleh pemerintah daerah.

\section{Perbandingan Pengawasan Perda oleh Pemerintah Pusat dalam UU Nomor 32 Tahun 2004 dan UU Nomor 23 Tahun 2014}

Undang-Undang Nomor 23 Tahun 2014 tentang Pemerintahan Daerah (UU Pemda 2014) dibentuk pada akhir masa jabatan periode kedua Presiden Susilo Bambang Yudhoyono. UU tersebut secara umum semakin memperkuat posisi pemerintah pusat, yang sebenarnya sudah mulai dilakukan secara bertahap dari mulai UU Pemda 2004. Pada pembahasan selanjutnya akan dianalisis mengenai perbandingan antara UU Pemda 2004 dan penggantinya, yaitu UU Pemda 2014. Pembahasan akan juga mengacu pada data-data yang bersumber dari penelitian lain yang telah dilakukan sebelumnya. Analisis terhadap kedua UU tersebut tidak

34 Dalam pilkada yang diatur dalam UU Pemda 1999 tidak ada peran yang signifikan dari pemerintah pusat dalam pilkada, selain urusan administrasi dalam hal pengesahan keputusan DPRD. Mekanisme itu dilatarbelakangi oleh pemikiran penguatan demokrasi di Indonesia pasca berakhirnya rezim otoritarian. Penguatan prinsip demokrasi perwakilan sangat terasa dalam kebijakan itu, namun patut disesalkan peningkatan prinsip demokrasi itu tidak dilaksanakan dalam kerangka negara kesatuan, yakni bentuk negara Indonesia yang sudah dicantumkan dalam konstitusi.

${ }^{35}$ Fitriani, Op.cit., hlm. 110-111. 
hanya akan menjabarkan perbedaan-perbedaan saja, tetapi juga melihat prospek perbaikan mekanisme pengawasan perda oleh pemerintah pusat. Ada tiga isu yang akan menjadi fokus dalam perbandingan, yaitu mekanisme pengawasan, bentuk hukum pembatalan perda, dan mekanisme banding terhadap pembatalan perda.

\section{Mekanisme Pengawasan Perda oleh Pemerintah Pusat}

Pembentukan UU Perda 2004 sebagai solusi dari banyaknya perda yang dibatalkan ternyata tidak membuahkan hasil. Pasca UU tersebut disahkan, ternyata pembatalan perda masih banyak terjadi. Selama kurun waktu 2004-2009, Kementerian Dalam Negeri (Kemendagri) telah membatalkan sebanyak 1.691 perda. Adapun persebaran data per-tahunnya adalah sebagai berikut: ${ }^{36}$

\begin{tabular}{|cccccc|}
\hline 2004 & 2005 & 2006 & 2007 & 2008 & 2009 \\
\hline 234 & 120 & 109 & 169 & 229 & 830 \\
\hline
\end{tabular}

Data di atas menunjukkan adanya kecenderungan pembatalan yang terus naik setiap tahunnya, terutama pasca tahun 2005 dalam hal pembatalan perda oleh pemerintah pusat, yang dalam hal ini dilakukan oleh Kemendagri. Kenaikan terbesar ada pada tahun 2008 ke tahun 2009. Peningkatan yang drastis ini disebabkan adanya pembatalan perda yang merupakan salah satu target program 100 hari pemerintahan SBY-Boediono periode 2009-2010. Jumlah perda yang dibatalkan hanya dalam waktu 100 hari tersebut mencapai 405 perda, yang melebihi capaian kerja Kemendagri dalam membatalkan perda sejak 2004-2008. ${ }^{37}$

Namun begitu, yang menjadi pertanyaan berikutnya adalah apakah perda yang dibatalkan merupakan produk periode waktu 2004-2009 atau sebelumnya? Berdasarkan penelitian yang dilakukan oleh Pusat Studi Hukum dan Kebijakan Indonesia (PSHK), ditemukan data bahwa mayoritas perda yang dibatalkan pada periode 2004-2009 tersebut dibentuk pada tahun 1999-2003, yaitu ketika masa keberlakuan UU Perda 1999. Adapun data lengkapnya adalah sebagai berikut:

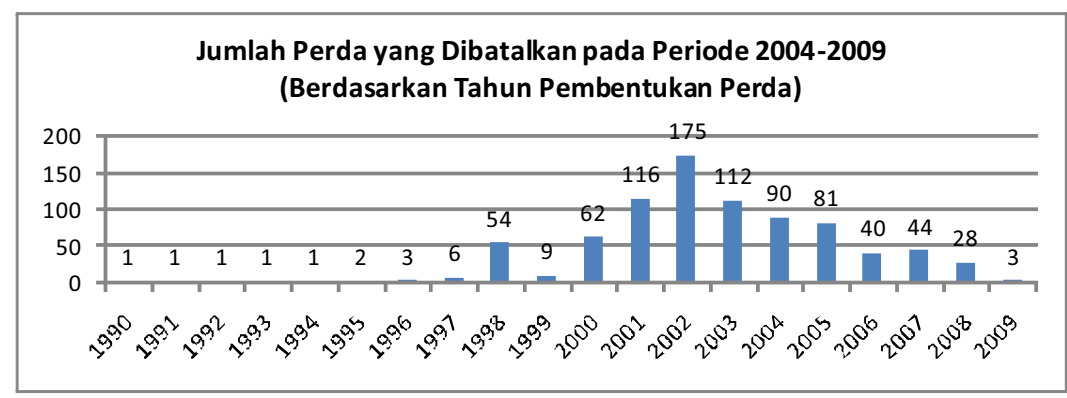

\footnotetext{
${ }^{36}$ Pusat Studi Hukum dan Kebijakan Indonesia, "Kajian tentang Implementasi Pengawasan Perda oleh Pemerintah dan Mahkamah Agung", Makalah Seminar Kajian Implementasi Pengawasan Perda oleh Pemerintah dan Mahkamah Agung, Maret, 2011, hlm. 26.

${ }^{37}$ Ibid.
} 
Dari data di atas, dapat diketahui bahwa kebebasan yang diberikan kepada pemerintah daerah dalam membentuk perda mampu menghasilkan lonjakan jumlah yang signifikan. Kebebasan itu pun ditandai dengan desakan demokratisasi yang sedang tinggi dan pengawasan yang minim, karena pada saat itu pengawasan yang dilakukan oleh pemerintah pusat hanya pengawasan preventif dengan kondisi yang serba terbatas.

Dari 1.691 perda yang dibatalkan pada 2004-2009, seluruhnya terdiri dari 121 jenis perda. Dari keseluruhan jenis tersebut, sebagian besar adalah perda yang mengatur perihal retribusi sebanyak 1.066 perda, meskipun tidak tertutup kemungkinan bahwa masih ada jenis perda lain yang juga merupakan perda pungutan. ${ }^{38}$ Jenis perda terbanyak kedua adalah perda pajak daerah dengan jumlah 224 perda. Posisi ketiga ditempati oleh perda perizinan dengan jumlah 179 perda. Dari data tersebut pada dasarnya dapat dianalisis bahwa di satu sisi pemerintah daerah bergerak cepat untuk menghasilkan perda retribusi dan pajak sebagai upaya meningkatkan pendapat daerah, tetapi di sisi lain pembentukannya tidak sesuai dengan kebijakan pemerintah pusat atau bahkan bertentangan dengan peraturan perundang-undangan yang lebih tinggi.

Banyaknya objek perda yang masuk dalam pengawasan berimbas pada panjangnya jangka waktu dalam proses evaluasi perda oleh pemerintah pusat. Permasalahan itulah yang coba diselesaikan oleh pengaturan dalam UU baru, yaitu UU Pemda 2014. Salah satu upaya yang dilakukan adalah dengan menerapkan proses pengawasan yang berjenjang, dengan cara perda kabupaten/kota diawasi oleh pemerintah daerah provinsi, sedangkan perda provinsi dilakukan oleh Menteri Dalam Negeri. Hal itu tidak dilakukan dalam UU Pemda 2004 yang memusatkan pengawasan kepada pemerintah pusat, dalam hal ini Menteri Dalam Negeri.

Permasalahan berikutnya adalah perihal lambatnya penyerahan perda oleh pemerintah daerah untuk dievaluasi, bahkan terdapat keengganan pemerintah daerah untuk menyerahkan perda untuk dilakukan evaluasi. Hal itu terjadi karena tidak ada sanksi yang diatur dalam UU Pemda 2004 kepada pemerintah daerah. Namun, dalam UU Pemda 2014 sudah ada sanksi yang diatur. Pada Pasal 249 ayat (2) diatur bahwa gubernur yang tidak menyampaikan perda provinsi dan peraturan gubernur kepada menteri dikenai sanksi administratif berupa teguran tertulis dari menteri, serta Pasal 249 ayat (4) dengan ketentuan yang sama dikenakan kepada bupati/wali kota yang tidak menyampaikan perda kabupaten/kota dan peraturan bupati/wali kota kepada gubernur sebagai wakil pemerintah pusat akan dikenai sanksi administratif berupa teguran tertulis dari gubernur sebagai wakil pemerintah pusat.

38 Ibid. 


\section{Bentuk Hukum Pembatalan Perda}

Dalam Pasal 145 ayat (3) UU Nomor 32 tahun 2004 disebutkan bentuk hukum untuk membatalkan perda ialah mengunakan Peraturan Presiden (selanjutnya disebut Perpres). Pada praktiknya, pembatalan perda dilakukan dengan menggunakan Keputusan Menteri Dalam Negeri (Kepmendagri). ${ }^{39}$ Hal tersebut mengindikasikan adanya kesalahan dalam pelaksanaan pembatalan perda selama ini.

Pada Pasal 251 ayat (1) UU Perda 2014 disebutkan bahwa pembatalan perda provinsi ditetapkan dengan keputusan menteri dan pembatalan perda kabupaten/kota ditetapkan dengan keputusan gubernur sebagai wakil pemerintah pusat. Kesan sentralistik semakin terasa pada ketentuan Pasal 251 ayat (3) yang dinyatakan bahwa menteri berwenang untuk membatalkan perda kabupaten/kota apabila gubernur sebagai perwakilan pemerintah pusat tidak melakukan kewajibannya itu.

Pilihan kebijakan dengan menempatkan menteri sebagai aktor yang dapat mengeluarkan keputusan untuk membatalkan suatu perda semakin mengindikasikan bahwa posisi pemerintah pusat sangat kuat terhadap pemerintah daerah. Hal itu dapat dibenarkan karena secara tegas menteri diberikan kewenangannya oleh UU. ${ }^{40}$ Pertanyaan mengenai legitimasi menteri tetap dapat dipertanyakan dengan merujuk atau melihat kepada proses pembentukan perda sendiri yang pada dasarnya sudah dapat dipersamakan dengan undang-undang, ${ }^{41}$ karena dibentuk oleh organ yang dipilih langsung oleh rakyat. Proses pembentukan perda pun mensyaratkan partisipasi masyarakat, berbeda dengan proses pembentukan peraturan menteri. Selain itu, perda juga merupakan salah satu peraturan perundang-undangan yang masuk dalam hierarki berdasarkan Pasal 7 Undang-Undang Nomor 12 Tahun 2011 tentang Pembentukan Peraturan Perundang-Undangan.

\section{Mekanisme Banding Pembatalan Perda oleh Pemerintah Pusat}

Banyaknya jumlah perda yang dibatalkan oleh Kemendagri setiap tahunnya tidak sebanding dengan jumlah perda yang di-review oleh Mahkamah Agung melalui mekanisme judicial review. Padahal kedua mekanisme ini diatur secara setara dalam ketentuan UU Pemda 2004. Pada tahun 2010, jumlah permohonan judicial review $^{42}$ mencapai 61 permohonan. Dari jumlah tersebut, hanya terdapat 12

\footnotetext{
39 Ibid., hlm. 29.

40 Suatu norma hukum selalu valid, tetapi dapat dibatalkan. Mekanisme pembatalan tidak perlu selalu dilakukan oleh produk hukum atau jabatan yang lebih tinggi. Aturan hukum yang lebih tinggi dapat memberikan kewenangan atau otoritas kepada organ khusus untuk melakukan pembatalan tersebut. Lihat, Jimly Asshiddiqie, Teori Hans Kelsen Tentang Hukum, Jakarta: Sekretariat Jenderal \& Kepaniteraan MKRI, 2006, hlm. 143.

41 Jimly Asshiddiqie, Menuju Negara Hukum yang Demokratis, Jakarta: Sekretariat Jenderal dan Kepaniteraan Mahkamah Konstitusi, 2008, hlm. 840.

42 Pusat Studi Hukum dan Kebijakan Indonesia, Loc.cit.
} 
permohonan judicial review perda. Sedangkan jenis peraturan yang paling banyak diajukan adalah peraturan menteri. ${ }^{43}$

Data itu menunjukan bahwa tidak banyak permohonan pengujian yang kemudian berakhir pada pembatalan melalui mekanisme di Mahkamah Agung sesuai dengan ketentuan dalam Pasal 145 ayat (5) UU Pemda 2004. Minimnya jumlah judicial review juga banyak disebabkan karena hal prosedural, seperti ketentuan dalam Pasal 2 Ayat (4) Peraturan Mahkamah Agung (Perma) Nomor 1 Tahun 2004 yang menyatakan bahwa permohonan keberatan diajukan dalam tenggang waktu 180 hari sejak ditetapkan peraturan perundang-undangan yang bersangkutan, proses yang berjalan tidak ditentukan jangka waktunya, dan judicial review dilakukan dengan proses tertutup.

Namun begitu, ternyata para pembentuk UU Pemda 2014 mengambil jalan pintas untuk mengatasinya, yaitu dengan menghilangkan sama sekali mekanisme yang dimaksud. Penghapusan mekanisme banding itu bisa dikatakan keliru, karena dengan adanya permasalahan itu bukan berarti mekanisme banding atau keberatan ke Mahkamah Agung menjadi dianggap tidak perlu. Di sisi lain, banyak akademisi yang menyatakan bahwa pengawasan yudisial oleh Mahkamah Agung dalam UU Pemda 2004 memberikan dampak positif, yaitu setidaknya meminimalkan dominasi kekuasaan pemerintah pusat atas pemerintah daerah yang telah menetapkan peraturan daerah secara demokratis. ${ }^{44}$

Selain itu, kewenangan Mahkamah Agung bukanlah tanpa dasar. Judicial review didasarkan pada Pasal 24A UUD RI 1945, sedangkan executive review secara harfiah pada dasarnya hanya berdasarkan pada peraturan setingkat UU, yaitu UU Pemda 2014 itu sendiri. Dalam praktik di berbagai negara, pengadilan menjadi mekanisme favorit dalam proses pembatalan perda, seperti yang dilakukan di Inggirs, Perancis, dan Belanda. ${ }^{45}$

\section{B. Penutup}

Kewenangan pengawasan yang dimiliki oleh pemerintah pusat terhadap perda yang disahkan oleh pemerintah daerah sebagai upaya pelaksanaan otonomi daerah tetap berada dalam kerangka Negara Kesatuan Republik Indonesia. Pasca kemerdekaan, hubungan antara pemerintah daerah dan pemerintah pusat, khususnya dalam aspek pengawasan, sudah mengalami dinamika yang tinggi. Perubahan demi perubahan yang terjadi sangat bergantung kepada pilihan kebijakan yang diambil oleh rezim berkuasa pada saat itu. Tarik menarik pendulum kekuasaan antara sentralisasi yang memperkuat pemerintah pusat atau

\footnotetext{
43 Ibid.

44 Pusat Studi Kajian Negara Fakultas Hukum Universitas Padjajaran, "Pola Hubungan Antara Pusat dan Daerah", Kerja Sama Penelitian dengan Dewan Perwakilan Daerah RI, 2009, hlm. 170.

${ }^{45}$ Fitriani, Op.cit., hlm. 201.
} 
desentralisasi yang memperkuat pemerintah daerah menjadi dua pilihan yang terus menjadi perdebatan klasik.

Perkembangan terakhir pasca reformasi, melalui UU Pokok-Pokok Pemda 1999, menunjukan bahwa pendulum diarahkan ke titik desentralisasi yang luas. Namun begitu, melalui UU Pemda 2004, pendulum itu diarahkan kembali pada kutub sentralisasi, yakni saat kekuasaan pemerintah pusat diperkuat. Pendulum semakin mengarah ke sisi sentralisasi ketika UU Pemda 2014 disahkan. Ada empat elemen yang membuktikan hal itu, yaitu konsep pengaturan mengenai pengawasan oleh pemerintah pusat dibuat secara hierarkis, pemberian sanksi kepada pemerintah daerah yang tidak menaati mekanisme pengawasan perda, kewenangan pemerintah pusat (dalam hal ini Menteri Dalam Negeri) yang dalam satu kondisi dapat membatalkan perda sampai kepada tingkat kabupaten/kota, dan penghapusan mekanisme banding atau keberatan pemeritah daerah terhadap pembatalan perda yang dilakukan oleh pemerintah pusat.

\section{Daftar Pustaka}

\section{Buku}

Bagir Manan, Menyongsong Fajar Otonomi Daerah, Pusat Studi Hukum Fakultas Hukum UII, Yogyakarta, 2001.

Barendt, Eric, An Introduction to Costitutional Law, Oxford University Press, Oxford, 1998.

Goodnow, Frank J., Politics and Administration, Transaction Publisher, Piscataway, 2003.

Harrop, Martin dan Rod Hague, Comparative Government and Politics, Fourth Edition, Palgrave, New York, 2001.

I Dewa Gede Atmadja, Ilmu Negara, Setara Press, Malang, 2011.

I Gde Pantja Astawa, Problematika Hukum Otonomi Daerah di Indonesia, Alumni, Bandung, 2009.

Jimly Asshiddiqie, Konsolidasi Naskah UUD 1945 Setelah Perubahan Keempat, Pusat Studi Hukum Tata Negara FH UI, Jakarta, 2002.

, Menuju Negara Hukum yang Demokratis, Sekretariat Jenderal dan Kepaniteraan Mahkamah Konstitusi, Jakarta, 2008.

, Pengantar IImu Hukum Tata Negara Jilid II, Sekretariat Jenderal

Mahkamah Konstitusi, Jakarta, 2006.

Mahfud M.D., Pergulatan Politik dan Hukum di Indonesia, Gama Medika, Jakarta, 1999.

Miriam Budiarjo, Dasar-dasar Ilmu Politik, Gramedia Pustaka Utama, Jakarta, 1998.

Montesquieu, Charles Louis, Complete Works Vol 1: The Spirits of Law, Liberty Fund Inc., Indiana, 2009. 
Ni'matul Huda, Problematika Pembatalan Perda, FH UII Press, Yogyakarta, 2010.

Satya Arinanto, Hak Asasi Manusia dan Transisi Politik di Indonesia, Pusat Studi Hukum Tata Negara FH UI, Jakarta, 2008.

Strong, C.F., Modern Political Constitutions, Sidgwick \& Jackson Limited, London, 1958.

\section{Dokumen Lain}

Fitriani Ahlan Sjarif, "Pengawasan Peraturan Daerah dalam Kerangka Negara Kesatuan (Tinjauan Historis dan Perbandingan Menurut UU Nomor 5 Tahun 1974, UU Nomor 22 Tahun 1999 dan UU Nomor 32 tahun 2004)", Tesis Pascasarjana FHUI, Jakarta, 2005.

Jimly Asshiddiqie, "Konstitusi dan Konstitualisme", http://jimly.com/pemikiran, diakses 20 Februari 2013.

Pusat Studi Hukum dan Kebijakan Indonesia, "Kajian Tentang Implementasi Pengawasan Perda Oleh Pemerintah Dan Mahkamah Agung", Seminar Kajian Tentang Implementasi Pengawasan Perda Oleh Pemerintah Dan Mahkamah Agung, Jakarta, Maret 2011.

Pusat Studi Kajian Negara Fakultas Hukum Universitas Padjajaran, "Pola Hubungan Antara Pusat dan Daerah", Kerjasama Penelitian dengan Dewan Perwakilan Daerah RI, Bandung, 2009.

\section{Dokumen Hukum}

Undang-Undang Dasar 1945.

Undang-Undang Dasar Republik Indonesia Serikat 1949.

Undang-Undang Dasar Sementara 1950.

Undang-Undang Dasar Negara Republik Indonesia1945.

Undang-Undang Nomor 22 Tahun 1948 tentang Penetapan Aturan-aturan Pokok

Mengenai Pemerintahan Sendiri di Daerah-daerah yang Berhak Mengatur dan Mengurus Rumah Tangganya Sendiri.

Undang-Undang Nomor 1 Tahun 1945 tentang Peraturan Mengenai Kedudukan

Komite Nasional Daerah.

Undang-Undang Nomor 1 Tahun 1957 tentang Pokok-pokok Pemerintahan.

Undang-Undang Nomor 5 Tahun 1974 tentang Pokok-pokok Pemerintahan Daerah.

Undang-Undang Nomor 22 Tahun 1999 tentang Pemeritah Daerah.

Undang-Undang Nomor 12 Tahun 2011 tentang Pembentukan Peraturan

Perundang-Undangan.

Undang-Undang Nomor 23 Tahun 2014 tentang Pemerintahan Daerah. 